\title{
PENGARUH PENGGUNAAN MEDIA AUDIO UNTUK MENINGKATKAN KEMAMPUAN MENGHAFAL AL-QUR'AN SISWA KELAS VIII PADA SMPIT AN-NAWAWI AL-BANTANI GUNUNG SINDUR BOGOR
}

\author{
AHMAD MASRURI \\ STIT Al-Amin Kreo Tangerang \\ ahmadmasruri@stitalamin.ac.id
}

\begin{abstract}
ABSTRAK
Penelitian ini tentang pengaruh penggunaan media audio untuk meningkatkan kemampuan menghafal ayat al-Qur'an terhadap siswa kelas VIII SMPIT An-Nawawi Al-Bantani. Melalui adanya penggunaan media audio untuk meningkatkan kemampuan menghafal ayat alQur'an diharapkan dapat mempermudah serta memotivasi siswa untuk mempelajari alQur'an khususnya dalam menghafalkannya. Penelitian dilakukan untuk menjawab beberapa masalah penelitian, yaitu: " a). Bagaimanakah hasil menghafal al-Qur'an sebelum menggunakan media audio?, b). Bagaimanakah hasil menghafal al-Qur'an setelah menggunakan media audio?, c) Apakah terdapat pengaruh penggunaan media audio dalam menghafal al-Qur'an ? Penelitian ini menggunakan pendekatan kuantitatif dengan metode kuasi eksperimen dan menggunakan desain one group time series design. Pada penelitian ini hanya melibatkan satu kelompok saja, yaitu kelompok eksperimen. Populasi pada penelitian ini adalah siswa kelas VIII SMPIT An-Nawawi Al-Bantani. Teknik pengambilan sampel dilakukan dengan cluster sampling. Instrumen yang digunakan adalah tes lisan. Kesimpulannya pada penelitian ini menunjukan bahwa adanya pengaruh signifikan penggunaan media audio untuk meningkatkan kemampuan menghafal ayat al-Qur'an. Kesimpulan khusus pada penelitian ini adalah terdapat pengaruh signifikan penggunaan media audio untuk meningkatkan kemampuan menghafal ayat al-Qur'an terhadap ketepatan melafalkan ayat, kelancaran menghafalkan ayat, dan kecepatan waktu menghafalkan ayat.
\end{abstract}

Kata Kunci: Audio, Menghafal, al-Qur'an, desain seri waktu satu kelompok 


\begin{abstract}
This research is about the effect of the use of audio media to improve the ability to memorize verses of the Qur'an against VIII grade students of An-Nawawi Al-Bantani SMPIT. Through the use of audio media to improve the ability to memorize the verses of the Qur'an, it is hoped that it can facilitate and motivate students to learn the Qur'an, especially in memorizing it. The study was conducted to answer several research problems, namely: "a). How is the result of memorizing the Qur'an before using audio media ?, b). How is the result of memorizing the Qur'an after using audio media ?, c) Is there any influence of the use of audio media in memorizing the Qur'an? This research uses a quantitative approach with a quasi-experimental method and uses one group time series design. In this study only involved one group, the experimental group. The population in this study were eighth grade students of An-Nawawi Al-Bantani Middle School. The sampling technique is done by cluster sampling. The instrument used was an oral test. The conclusion in this study shows that there is a significant influence on the use of audio media to improve the ability to memorize the verses of the Qur'an. The special conclusion in this study is that there is a significant influence of the use of audio media to improve the ability to memorize verses of the Qur'an on the accuracy of reciting verses, fluency in memorizing verses, and speed of memorizing verses.
\end{abstract}

Keywords: Audio, Memorization, al-Qur'an, design of a group time series 


\section{A. PENDAULUAN}

Islam merupakan agama yang Allah SWT turunkan sebagai agama yang penuh dengan rahmat dan keberkahan. Allah menurunkan agama sejatinya untuk menjadikan kendali, patokan, pegangan untuk mencapai kebahagian yang hakiki.Tentunya Allah SWT tidak akan membiarkan hambanya terombang-ambing tanpa Adanya pedoman, maka al-Qur'an hadir untuk menjawab setiap permasalahan Manusia. ${ }^{1}$ Al-Qur'an adalah kitab Allah. Setiap kali seorang muslim membaca, mencintai dan menghafalnya maka Allah akan mengaruniakan kepadanya pemahaman yang benar. Memahami materi-materi pelajaran, baik yang bersifat umum maupun spiritual. Pemahaman yang benar hanya Allah berikan kepada para walinya, yang mereka itu adalah ahli al-Qur'an (Para penghafal AlQur'an). ${ }^{2}$ Allah berfirman:

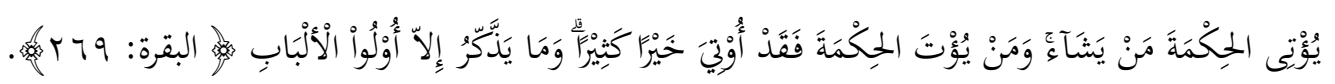

“Allah menganugerahkan Al-Hikmah (Kepahaman yang dalam tentang alQur'an dan As-Sunnah) kepada siapa yang dikehendaki-Nya. Dan barag siapa yang dianugerahi hikmah, ia benar-benar telah dianugerahi karunia yang banyak. Dan hanya orang-orang yang berakallah yang dapat mengambil pelajaran (dari firman Allah)."(QS. Al-Baqarah: 269).

Perkembangan kognitif salah satunya mencakup perkembangan ingatan atau memori. Memori pada anak akan sangat lebih mudah merekam informasi yang sengaja diberikan ataupun informasi yang didapatnya sendiri. Desmita menyatakan bahwa : "mengukur memori anak-anak jauh lebih mudah, karena anak-anak telah dapat memberikan reaksi secara verbal". ${ }^{3}$ Berdasarkan penjelasan dari berbagai sumber yang mendukung, bahwa masa anak merupakan masa emas, saat memori anak sangat lebih mudah menerima informasi serta mampu mengungkap kembali secara verbal dibanding orang dewasa. Hal ini perlu disadari selain usia, banyak faktor lain yang mempengaruhi jangka waktu lama dan tidak lamanya daya ingat pada individu.

Salah satu pendukung yang mempengaruhi informasi lama dan tidak lamanya daya ingat adalah pengulangan informasi, pembiasaan dalam bentuk latihan yang bisa menjadi terbiasa dan adanya kejadian atau pengalaman yang dialami yang menimbulkan kesan senang atau sedih sehingga masuk pada memori jangka panjang. Seperti yang telah dijelaskan oleh Rahman Tri Putra dalam artikelnya: "Memori jangka panjang memungkinkan kita mengingat sesuatu lebih

${ }^{1}$ Nurul Fauzia, Pengaruh penggunaan media audio untuk meningkatkan kemampuan menghafal ayat al-quran (Bandung: UPI, 2015), 89.

2 Yahya Abdul Fattah, Revolusi Menghafal Al-Qur'an (Surakarta: Insan Kamil, 2010), 37.

3 Desmita, Psikologi Perkembangan (Bandung: PT Remaja Rosdakarya, 2005), 134. 
lama dan lebih banyak bahkan tak terbatas sampai seumur hidup. Proses penyimpanan memori mulai dari sebuah memori masuk ke memori jangka pendek. Semakin lama memori itu tersimpan di memori jangka pendek semakin besar kemungkinan memori itu untuk masuk ke memori jangka panjang. Pengulangan atau latihan juga bisa meningkatkan kemungkinan untuk menyimpan memori di memori jangka panjang". ${ }^{4}$

Berbagai cara untuk melatih daya ingat, salah satunya yaitu dengan cara pembiasaan. Seperti yang sudah dibahas sebelumnya, bahwa salah satu cara untuk meningkatkan kinerja memori yaitu dengan cara menghafal al-Qur'an. Hal ini ada hubungannya dengan latihan pembiasaan dalam pembelajaran menghafal. Mengingat juga, bahwa momen emas yang dimanfaatkan pada masa anak yang akan lebih mudah menerima informasi yang didapat. Latihan atau pengulangan dalam menghafalkan al-Qur'an pun akan menjadi penguatan bagi daya ingat anaksehingga meningkatkan kemampuan menghafal yang baik, berkualitas, dan jangka panjang. Dalam jurnal ilmiah didaktika Fithriani Gade tentang implementasi metode tiqrar dalam pembelajaran menghafal al-Qur'an : "proses menghafal dan pengulangan ini akan membuat para penghafal al-Qur'an mampu memeliharakan ayat-ayat yang dihafalnya dengan baik". ${ }^{5}$ Seperti yang telah dipaparkan, bahwa dengan cara pengulangan akan menguatkan serta memelihara hafalan al-Qur'an.

Selain itu, menghafalkan al-Qur'an juga mampu melatih fokus anak, mempelajari serta mengenalkan nilai-nilai agama sesuai al-Qur'an dan As-sunah. Seperti yang dialami oleh kebanyakan orang, dengan terbiasanya mendengarkan adzan, membaca dan mendengarkan imam sedang shalat membaca surat al-Fatihah secara berulang-ulang, tanpa dihafalkan pun akan menjadi hafal dengan sendirinya. Sama halnya ketika orang Sunda yang tinggal di Jawa bertahun-tahun, perlahan lahan logat atau cara mengucapkan kata akan mengikuti orang Jawa, yang akan menjadi pembiasaan yang melekat. Begitupun dengan menghafalkan al-Qur'an dengan cara pembiasaan sering melihat, mendengar, dan mempelajarinya, akan mudah hafal dan terbiasa. Hal ini berbeda dengan kebanyakan orang beranggapan bahwa menghafal adalah tugas yang monoton, membosankan, susah, dan rumit.

Menghafal dengan cara yang monoton membuat kesan proses pembelajaran dengan cara menghafal menjadi kurang menarik, malas dan membuat kantuk. Pada zaman sekarang minat untuk mempelajari al-Qur'an semakin berkurang, karena kurangnya motivasi serta kesadaran diri bahwa pentingnya mempelajari al-Qur'an, baik membaca ayat-ayatnya, menghafal dan mentadabburinya adalah hal yang sangat berat dilakukan sebagian orang, bahkan menurut sebagian anak-anak milenial kegiatan menghafal al-Qur'an adalah suatu kesia-siaan dan membuang waktu untuk menikmati masa muda mereka yang bisa diisi dengan kesenangan

\footnotetext{
${ }^{4}$ Rahman Tri Putra,Memori, http://www.memoripedia.byethost7.com/definisi.html 2015.

${ }^{5}$ Fithriani gade, "Implementasi Metode Takrar Dalam Pembelajaran MenghafalAl-Qur'an", Jurnal Didaktika, Vol XIV, No, 2, 2015: 413-425.
} 
duniawi, dikutip dari artikel yang menunjukan bahwa hasil penelitian Institut Ilmu al-Qur'an tahun 2013 menunjukkan bahwa 65\% umat Islam di Indonesia masih buta aksara al-Qur'an, 35\% hanya bisa membaca al-Qur'an saja, dan hanya 20\% yang dapat membaca alQur'an dengan baik. Hal tersebut merupakan fakta yang ironis, memprihatinkan, sekaligus mengkhawatirkan karena umat Islam adalah umat mayoritas dari sekitar 250 jutaan jumlah penduduk Indonesia. Kondisi tersebut yang melatarbelakangi Gubernur Jabar Ahmad Heryawan meluncurkan program Jabar menghafal. Aher meresmikan Gerakan Jabar Menghafal al-Qur'an di sejumlah daerah seperti Kota Bandung, Cianjur, Garut, Purwakarta, Cianjur, Sukabumi, dan Cirebon. Sasaran program ini seluruh siswa mulai dari jenjang SD sampai dengan SMA sekitar sembilan juta orang. Bertujuan untuk mendekatkan dan mengakrabkan kembali generasi muda Islam Jawa Barat dengan al-Qur'an, jangan sampai buta huruf al-Qur'an. Kondisi saat ini menunjukkan bahwa umat Islam semakin jauh dari al-Qur'an, bahkan banyak yang belum bisa membaca Al-Qur'an. ${ }^{6}$

Dilihat dari data diatas dapat disimpulkan bahwa sebagian besar penduduk Indonesia tidak mampu membaca al-Qur'an. Hal ini mungkin disebabkan oleh beberapa faktor, seperti tidak adanya motivasi untuk mempelajarinya. Sehingga mendapat perhatian khusus dan kembali berupaya untuk mendekatkan kembali generasi mudanya menjadi generasi yang cinta al-Qur'an. Diharapkan dengan upaya menciptakan generasi muda yang cinta al-Qur'an, pembelajaran al-Qur'an dengan baik, mudah, dan menyenangkan akan membantu sebagian kecil masalahmasalah yang dialami, sehingga mampu merangsang motivasi serta kesadaran diri bahwa begitu pentingnya mempelajari al-Qur'an. Sesuai dengan penjelasan tersebut, memadukan konsep menghafal dengan latihan atau pembiasaan semoga menjadi salah satu kontribusi untuk kembali menumbuhkan motivasi dan menciptakan pembelajaran al-Qur'an yang lebih baik.

Melalui media, proses pembelajaran al-Qur'an akan menjadi pilihan yang tepat untuk meningkatkan motivasi dan menjadi daya tarik. Salah satu contoh media yang tepat untuk meningkatkan kemampuan menghafal ayat al-Qur'an yaitu dengan menggunakan media audio. Arief Sadiman, dkk. menyatakan bahwa kegunaan media pendidikan secara tepat dan bervariasi dapat mengatasi sikap pasif anak didik. Sehingga berguna untuk menimbulkan kegairahan belajar, memungkinkan interaksi langsung dengan lingkungannya, dan memungkinkan anak didik belajar sendiri. ${ }^{7}$ Berdasarkan penjelasan tersebut bahwa dengan media akan menjadi salah satu cara untuk menyajikan proses belajar mengajar menjadi lebih bervariasi. Dengan media pembelajaran yang peneliti pilih untuk meningkatkan kemampuan menghafal ayat al-Qur'an yaitu dengan media yang mengoptimalkan pendengaran yaitu media audio. Media audio merupakan salah

6 IdrisApandi, Gerakan Jabar Menghafal, 2015, http://www.kompasiana.com/idrisapandi /gerakan-jabar-menghafal-al-quran54fd1d81a333113f1d50f85f.

7 Arief Sadiman, dkk. ,Media Pendidikan: Pengertian Pengembangan dan Pemanfaatannya, (Jakarta: Rajawali Pers, 2010), 17. 
satu cara atau upaya untuk memudahkan proses pembelajaran khususnya pada pembelajaran Al-Qur'an untuk meningkatkan kemampuan menghafal ayat-ayat AlQur'an, dengan cara penguatan dan pengulangan. Media audio ini biasanya dilakukan dengan cara guru membacakan Al-Qur'an dengan melihat mushaf, kemudian murid mendengarkan bacaan maupun dengan menggunakan media, seperti CD, Player.MP3, MP4, kemudian kaset diputar didengarkan sambil mengikuti perlahan-lahan, diulang lagi sampai ayat-ayat sudah bisa dihafal dengan baik dan benar.

Media audio digunakan untuk mempermudah anak didik untuk melafalkan surat pendek, karena media audio merupakan bahan yang mengandung pesan dalam bentuk auditif sehingga dapat merangsang pikiran, perasaan, perhatian, dan kemauan anak didik, sehingga terjadi proses belajar mengajar.Pembelajaran dengan menggunakan media audio menjadi strategi yang tepat untuk menghafalkan AlQur'an. Proses menghafal dengan menggunakan media audio adalah perantara untuk memudahkan peserta didik menghafal. Bukan hanya dengan bacaan gurunya saja di kelas, akan tetapi peserta didik bisa mengulang-ulang ayat dengan menggunakan media audio. Pemanfaatan media audio sangat mempermudah pembelajaran menghafal ayat Al-Qur'an sehingga dikemas menjadi lebih menarik dan bermakna. Selain itu juga media audio mampu melatih fokus anak didik dalam menyimak

\section{B. METODE}

Penelitian ini menggunakan metode Kuasi Eksperimen (Quasi Experiment), yaitu, penelitian yang digunakan untuk mengetahui ada tidaknya akibat dari sesuatu yang dikenakan pada subjek yang diteliti dengan mencari pengaruh perlakuan tertentu terhadap yang lain dalam kondisi yang terkendali. ${ }^{8}$ Penggunaan metode kuasi eksperimen ini bertujuan untuk mengetahui atau memperoleh gambaran yang akan terjadi tehadap variabel setelah dilakukan perlakuan pada variabel lainnya. Penelitian yang akan dilakukan hanya pada kelas eksperimen saja yang sebelumnya akan diberikan tes dan setelah perlakuan akan kembali diberikan tes.

Pada penelitian eksperimen ini peneliti ingin melihat apa yang terjadi pada variabel terikat $(\mathrm{Y})$ yang mampu ditimbulkan sebab perlakuan yang diterapkan dalam veriabel bebas. Variabel pada penelitian ini pengaruh penggunaan media audio di tempatkan sebagai variabel $(X)$ atau variabel bebas, sedangkan untuk meningkatkan kemampuan menghafal di tempatkan sebagai variabel (Y) atau variabel terikat. Desain penelitian antara variabel bebas dan variabel terikat dapat dilihat sebagai berikut.

${ }^{8}$ Sugiyono, Metode Penelitian Pendidikan (Bandung: CV.Alfabeta, 2008), 60. 
Adapun jenis desain yang digunakan adalah Quasi Experiment dengan one group pretest and posttest adalah suatu teknik untuk mengetahui efek sebelum dan sesudah pemberian perlakuan. ${ }^{9}$

Secara bagan, desain kelompok tunggal desain pretest dan posttest dapat digambarkan sebagai berikut:

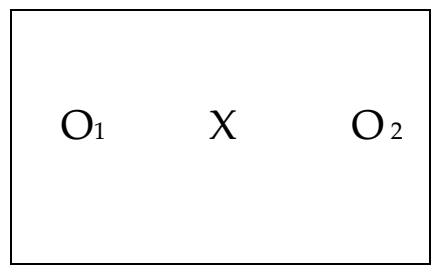

Gambar 3.1

$\mathrm{O}_{1}=$ nilai pre test (sebelum diberi perlakuan)

$\mathrm{O}_{2}=$ nilai Post test (sesudah perlakuan)

$\mathrm{X}=$ perlakuan

Dalam desain ini, sebelum diberikan perlakuan diawal akan diberikan pretes sebagai tes awal yang akan dilihat dan dihitung rata-rata yang menunjukan kemampuan yang dimiliki siswa sebelumnya, kemudian akan ada perlakuan, yaitu pengaruh penggunaan media audio untuk meningkatkan kemampuan menghafal, setelah diberikan perlakuan akan diberikan lagi postes sebagai tes akhir untuk melihat hasil kemampuan menghafal setelah diberikan perlakuan. Jika diantara pretes dan postes terdapat perbedaan yang signifikan, maka dapat disimpulkan bahwa perbedaan atau perubahan tersebut merupakan pengaruh dari perlakuan. "Pengaruh perlakuan $\mathrm{X}$ dapat diketahui dengan membandingkan antara hasil $\mathrm{O}_{1}$ dan $\mathrm{O}_{2}$ dalam situasi yang terkontrol. ${ }^{10}$

Jika dilihat dari Hubungan Kausal, terdapat 2 (dua) variabel yang bersifat saling memengaruhi antara variabel yang satu (variabel bebas) terhadap variabel lain (variabel tak bebas). Dalam bentuk ini, hubungan diketahui dengan pasti atau dapat dibedakan variabel bebas (variabel yang mempengaruhi dengan variabel terikat (variabel yang dipengaruhi). Kedua variabel tersebut yaitu:

1. Variabel bebas $(X)$ independen yaitu variabel yang mempengaruhi variabel lain.

2. Variabel terikat $(\mathrm{Y})$ dependen yaitu variabel yang dipengaruhi oleh variabel lain. Peningkatan kemampuan Hafalan siswa sebagai variabel terikat (Y) dengan indikator sebagai berikut : a) Kelancaran hafalan al-Qur'an; b) Ketepatan hafalan al-Qur'an; c) Kecepatan waktu menghafal al-Qur'an.

Populasi adalah sejumlah masa (manusia atau bukan) yang terdapat dalam kawasan tertentu dalam satu unit kesatuan. Populasi pada penelitian ini adalah seluruh siswa kelas VIII Pondok Pesantren SMPIT An-Nawawi Al-Bantani yang

${ }^{9}$ Sugiyono, Metode Penelitian Kuantitatif (Bandung: CV Alfabeta, 2008), 115.

${ }^{10}$ Zainal Arifin, Penelitian Pendidikan (Bandung: PT.Remaja Rosdakarya, 2011), 77. 
terdiri dari 108 siswa, sekolah ini bertempat di kp. Bulak Saga, RT. 03/06, Ds. Cibadung, Kec. Gunung Sindur, Kab. Bogor.

Tabel. 1.

Siswa SMPIT An-Nawawi Al-Bantani, Gunung sindur, Bogor

\begin{tabular}{|c|c|c|}
\hline No. & Kelas & Jumlah Siswa \\
\hline 1 & VIIIA & 27 \\
\hline 2 & VIIIB & 27 \\
\hline 3 & VIIIC & 28 \\
\hline 4 & VIIID & 26 \\
\hline & Jumlah Total & 108 \\
\hline
\end{tabular}

Teknik sampling yang digunakan dalam penelitian ini adalah cluster sampling. Pengambilan pada teknik ini yaitu mengambil sampel berdasarkan sekelompok individu . Pada penelitian ini, sampel yang digunakan yaitu kelas VIIIA yang berjumlah 27 orang kelas VIII Pondok Pesantren SMPIT An-Nawawi Al-Bantani, sekolah ini bertempat di Kp. Bulak Saga, RT. 03/06 Ds. Cibadung, Kec. Gunung Sindur, Kab. Bogor.

Selanjutnya proses pengumpulan data primer dan sekunder dalam penelitian ini dapat dirumuskan melalui:

1) Metode Tes

Tes yang digunakan dalam penelitian ini adalah tes lisan yang penilaiannya mengacu pada aspek kelancaran, ketepatan, dan kecepatan waktu menghafal. Kriteria Penilaian

- Tes kelancaran Hafalan Siswa:

Skor 4 : Sangat Lancar

Skor 3 : Lancar

Skor 2 : Kurang Lancar

Skor 1 : Tidak Lancar

- Tes Ketepatan Hafalan Siswa:

Skor 4 : Sangat Lancar

Skor 3 : Lancar

Skor 2 : Kurang lancar 
Skor 1 : Tidak lancar

- Tes kecepatan waktu hafalan siswa:

Skor 4 : 1-15 menit

Skor 3 : 16-30 menit

Skor $2: 31-45$ menit

Skor 1 : 46-60 menit

Adapun variabel peningkatan hafalan siswa diperoleh melalui tes lisan hafalan al Qur'an dengan menekankan pada aspek kelancaran, ketepatan dan kecepatan waktu menghafal. Pada penelitian kuantitatif kegiatan analisis datanya meliputi pengolahan data dan penyajian data, melakukan perhitungan untuk mendiskripsikan data dan melakukan pengujian hipotesis dengan menggunakan uji statistik. ${ }^{11}$ Setelah data terkumpul, maka langkah selanjutnya adalah menganalisis data tersebut. Dalam analisis ini penulis menggunakan teknik analisis data statistik karena jenis penelitiannya adalah kuantitatif. Tujuan analisis ini adalah menyederhanakan data ke dalam bentuk yang lebih mudah dibaca dan diinterpretasikan. ${ }^{12}$ Teknik statistik yang digunakan dalam menganalisis hubungan ini menggunakan teknik koefisien korelasi. Koefisien korelasi adalah bilangan yang menyatakan kekuatan hubungan antara dua variabel atau lebih juga dapat menentukan arah hubungan dari kedua variabel. ${ }^{13}$ Dalam penelitian ini, terlebih dahulu peneliti menjumlahkan instrumen-instrumen uji pretes (sebelum perlakuan), dan uji postes (setelah perlakuan, kemudian menentukan nilai mean, median, modus, simpangan baku,range, nilai minimum dan juga nilai maksimum engan menggunakan bantuan program software spss22.0 untuk windows.

Selanjutnya, untuk mengetahui ada tidaknya hubungan antara pretes dengan postes, maka peneliti menggunakan analisis statistik yaitu analisis koefisien korelasi pearson product moment. ${ }^{14}$

\section{PEDOMAN UNTUK MEMBERIKAN INTERPRETASI KOEFISIEN KORELASI}

\begin{tabular}{|c|c|}
\hline Interval Koefisien & Tingkat Hubungan \\
\hline $0,00-0,199$ & Sangat Rendah \\
\hline $0,20-0,399$ & Rendah \\
\hline $0,40-0,599$ & Sedang \\
\hline $0,60-0,799$ & Kuat \\
\hline $0,80-1,000$ & Sangat Kuat \\
\hline
\end{tabular}

11 Syofian Siregar, Statistik Parametrik Untuk Penelitian Kuantitatif, 125.

12 Mari Singarimbun dan Sofian Effendi, Metode Penelitian Survei (Jakarta, LP3ES,1995), 263.

13 Syofian siregar, Statistik Parametrik Untuk Penelitian Kuantitatif, 337.

14 Sugiyono, Metode Penelitian Kuantitatif ((Bandung: CV Alfabeta, 2008), 274. 
Setelah penetapan interpretasi koefisien korelasi, maka perlu diuji signifikansinya. Rumus uji signifikansi korelasi product moment sebagai berikut.

$$
\begin{aligned}
& \mathrm{t}= \underline{r \sqrt{n-2}} \\
& \sqrt{1-(r)^{2}}
\end{aligned}
$$

Instrumen penelitian adalah suatu alat yang dapat digunakan untuk memperoleh, mengolah, dan menginterpretasikan informasi yang diperoleh dari para responden yang dilakukan dengan menggunakan pola ukur yang sama. Dalam penelitian ini terdapat dua variabel, yaitu media Audio sebagai variabel bebas $(X)$ dan Peningkatan hafalan sebagai variabel terikat (Y). Variabel Peningkatan hafalan siswa merupakan variabel yang bersifat individual dan subyektif, maka untuk mengukur variabel penelitian ini digunakan metode Pretest (tes sebelum perlakuan) dan Posttest (tes sesudah perlakuan).

1. Uji-t

Uji-t merupakan statistik parametrik, untuk mengujinya maka dibutuhkan langkah-langkah sebagai berikut:

a) Membuat hipotesis dalam uraian kalimat

Ho : Tidak terdapat hubungan antara penggunaan media audio dengan kemampuan hafalan al Qur'an siswa.

Ha : Terdapat hubungan antara penggunaan media audio dengan kemampuan hafalan al Qur'an siswa

b) Membuat Hipotesis dalam Bentuk Model Statistik

$$
\text { Ho }: r=0
$$

Ha $: r \neq 0$

c) Menentukan Kaidah Pengujian

Jika, -ttabel $\leq$ thitung $\leq$ ttabel, maka Ho diterima.

Jika, thitung $>$ ttabel, maka Ho ditolak.

d) Menghitung thitung dan ttabel ${ }^{15}$

thitung $=\underline{r \sqrt{n-2}}$

$$
\sqrt{1-(r)^{2}}
$$

e) Menentukan ttabel

Nilai ttabel dapat dicari dengan menggunakan tabel distribusi $t$ dengan cara, taraf signifikan $\alpha=0,05$. Kemudian dicari ttabel pada tabel distribusi student $t$ dengan ketentuan $t(\alpha, \mathrm{n}-2)$.

f) Membandingkan nilai thitung dan ttabel 
Tujuan membandingkan ttabel dan thitung adalah untuk mengetahui apakah Ho ditolak atau diterima berdasarkan kaidah pengujian di atas.

\section{Teknik Probabilitas}

a) Membuat hipotesis dalam uraian kalimat

Ho : Tidak terdapat pengaruh dalam penggunaan media audio terhadap kemampuan hafalan siswa.

Ha : Terdapat pengaruh dalam penggunaan media audio terhadap kemampuan hafalan siswa.

b) Keputusannya

Kriteria keputusan yang diambil berdasarkan nilai probabilitas.

Jika (sig) $>\alpha$, maka Ho diterima.

\section{HASIL DAN PEMBAHASAN}

Analisis hubungan (korelasi) adalah suatu bentuk analisis data dalam penelitian yang bertujuan untuk mengetahui kekuatan atau bentuk arah hubungan di antara dua variabel dan besarnya pengaruh yang disebabkan oleh variabel yang satu (variabel bebas) terhadap variabel lainnya (variabel terikat). Dalam menganalisis hubungan, penelitian ini termasuk ke dalam bentuk hubungan kausal. Hubungan kausal adalah hubungan antara dua variabel atau lebih, yang bersifat memengaruhi antara variabel yang satu (variabel bebas) terhadap variabel lain (variabel tak bebas). Dalam bentuk ini, hubungan diketahui dengan pasti atau dapat dibedakan variabel bebas (variabel yang memengaruhi) dengan variabel terikat (variabel yang dipengaruhi). Variabel bebas $(X)=$ Penggunaan Media Audio (Mempengaruhi). Variabel tak bebas $(\mathrm{Y})=$ Kemampuan Hafalan Al-Qur'an Siswa (dipengaruhi).

Teknik statistik yang digunakan dalam menganalisis hubungan variabel bebas $(\mathrm{X})$ dengan variabel tak bebas $(\mathrm{Y})$ menggunakan teknik analisis koefisien korelasi Pearson Product Moment.

1. Instrumen Penilaian pretest-posttest

Tabel. 2.

Nilai Pretes

\begin{tabular}{|c|c|c|c|c|c|c|}
\hline $\begin{array}{c}\text { No } \\
.\end{array}$ & Ketepatan & Kelancaran & $\begin{array}{c}\text { Kecepatan } \\
\text { Waktu }\end{array}$ & $\begin{array}{c}\text { Jumlah } \\
\text { Skor }\end{array}$ & $\begin{array}{c}\text { Nilai } \\
\text { Tahfidz }\end{array}$ & $\begin{array}{c}\text { Nilai } \\
\text { Akhir }\end{array}$ \\
\hline 1. & 4 & 4 & 4 & 12 & 8 & 96 \\
\hline 2. & 4 & 3 & 4 & 11 & 8 & 88 \\
\hline 3. & 4 & 4 & 3 & 11 & 8 & 88 \\
\hline 4. & 3 & 3 & 4 & 10 & 8 & 80 \\
\hline 5. & 3 & 3 & 4 & 10 & 8 & 80 \\
\hline 6. & 3 & 2 & 4 & 9 & 8 & 72 \\
\hline 7. & 3 & 3 & 3 & 9 & 8 & 72 \\
\hline
\end{tabular}




\begin{tabular}{|r|l|l|l|l|l|l|}
\hline 8. & 3 & 2 & 4 & 9 & 8 & 72 \\
\hline 9. & 4 & 2 & 3 & 9 & 8 & 72 \\
\hline 10. & 3 & 2 & 3 & 8 & 8 & 64 \\
\hline 11. & 3 & 2 & 3 & 8 & 8 & 64 \\
\hline 12. & 3 & 2 & 3 & 8 & 8 & 64 \\
\hline 13. & 3 & 2 & 3 & 8 & 8 & 64 \\
\hline 14. & 2 & 3 & 3 & 8 & 8 & 64 \\
\hline 15. & 3 & 2 & 3 & 8 & 8 & 64 \\
\hline 16. & 2 & 3 & 3 & 8 & 8 & 64 \\
\hline 17. & 3 & 2 & 3 & 8 & 8 & 64 \\
\hline 18. & 3 & 2 & 3 & 8 & 8 & 64 \\
\hline 19. & 2 & 2 & 3 & 7 & 8 & 56 \\
\hline 20. & 2 & 2 & 3 & 7 & 8 & 56 \\
\hline 21. & 2 & 2 & 3 & 7 & 8 & 56 \\
\hline 22. & 2 & 2 & 3 & 7 & 8 & 56 \\
\hline 23. & 2 & 2 & 3 & 7 & 8 & 56 \\
\hline 24. & 2 & 2 & 3 & 7 & 8 & 56 \\
\hline 25. & 2 & 2 & 3 & 7 & 8 & 56 \\
\hline 26. & 3 & 2 & 2 & 7 & 8 & 56 \\
\hline 27. & 2 & 1 & 3 & 6 & 8 & 48 \\
\hline
\end{tabular}

Dari tabel diatas diperoleh presentase nilai 96 diraih oleh satu orang siswa, nilai ini adalah presentase nilai tertinggi yang sudah ditetapkan peneliti, sedangkan nilai 88 diraih oleh 2 orang siswa, nilai 80 diraih oleh 2 orang siswa, nilai 72 diraih oleh 4 orang siswa, nilai 64 diraih oleh 9 orang siswa, nilai 56 diraih oleh 8 orang, dan nilai 48 diraih oleh satu orang siswa. Peneliti mengurutkan nilai dari yang terbesar untuk melihat seberaba besar pengaruh penggunaan media audio terhadap peningkatan hafalan Al-Qur'an bagi siswa.

Tabel. 3.

Nilai Postes

\begin{tabular}{|c|c|c|c|c|c|c|}
\hline No. & Ketepatan & Kelancaran & $\begin{array}{c}\text { Kecepatan } \\
\text { Waktu }\end{array}$ & Jumlah Skor & $\begin{array}{c}\text { Nilai } \\
\text { Tahfidz }\end{array}$ & $\begin{array}{c}\text { Nilai } \\
\text { Akhir }\end{array}$ \\
\hline 1. & 4 & 4 & 4 & 12 & 8 & 96 \\
\hline 2. & 4 & 4 & 4 & 12 & 8 & 96 \\
\hline 3. & 4 & 3 & 4 & 11 & 8 & 88 \\
\hline 4. & 4 & 3 & 4 & 11 & 8 & 88 \\
\hline 5. & 4 & 3 & 4 & 11 & 8 & 88 \\
\hline 6. & 4 & 3 & 4 & 11 & 8 & 88 \\
\hline 7. & 4 & 3 & 4 & 11 & 8 & 88 \\
\hline 8. & 4 & 3 & 3 & 10 & 8 & 80 \\
\hline
\end{tabular}




\begin{tabular}{|c|c|c|c|c|c|c|}
\hline 9. & 4 & 3 & 3 & 10 & 8 & 80 \\
\hline 10. & 3 & 3 & 4 & 10 & 8 & 80 \\
\hline 11. & 4 & 3 & 2 & 9 & 8 & 72 \\
\hline 12. & 3 & 2 & 3 & 8 & 8 & 64 \\
\hline 13. & 3 & 2 & 3 & 8 & 8 & 64 \\
\hline 14. & 3 & 2 & 3 & 8 & 8 & 64 \\
\hline 15. & 2 & 2 & 3 & 7 & 8 & 56 \\
\hline 16. & 2 & 2 & 3 & 7 & 8 & 56 \\
\hline 17. & 2 & 2 & 3 & 7 & 8 & 56 \\
\hline 18. & 3 & 2 & 2 & 7 & 8 & 56 \\
\hline 19. & 2 & 2 & 2 & 6 & 8 & 48 \\
\hline 20. & 2 & 2 & 2 & 6 & 8 & 48 \\
\hline 21. & 2 & 2 & 2 & 6 & 8 & 48 \\
\hline 22. & 2 & 1 & 2 & 5 & 8 & 40 \\
\hline 23. & 2 & 1 & 2 & 5 & 8 & 40 \\
\hline 24. & 2 & 1 & 2 & 5 & 8 & 40 \\
\hline 25. & 2 & 1 & 1 & 4 & 8 & 32 \\
\hline 26. & 1 & 1 & 1 & 3 & 8 & 24 \\
\hline 27. & 1 & 1 & 1 & 3 & 8 & 24 \\
\hline
\end{tabular}

Dari tabel postes diatas dapat dilihat perbedaan signifikan pada nilai nilai hafalan siswa, pada pretes sebelumnya hanya sedikit siswa yang meraih nilai sempurna,tapi poin terkecilnya adalah 48 yang diraih oleh seorang siswa, sedangkan pada tabel posttes nilai 96 diraih oleh 2 orang siswa, nilai 88 diraih oleh 5 orang siswa, nilai 80 diraih oleh 3 orang siswa, nilai 72 diraih oleh 1 orang siswa, nilai 64 diraih oleh 3 orang siswa, nilai 56 diraih oleh 4 orang siswa, nilai 48 diraih oleh 3 oang siswa, nilai 40 diraih oleh 3 orang, nilai 32 diraih oleh 1 orang siswa, dan nilai 24 diraih oleh 2 orang siswa. Nilai 24 adalai skor nilai terkecil pada skala pretes dan postes ini.

Dapat ditarik kesimpulan dari tabel diatas bahwa beberapa siswa yang dominan menghafal dengan metode visual akan mengalami penurunan skor nilai pada postes mereka, dan adapun siswa yang dominan dengan menggunakan media audio mereka pada hafalan, hafalan mereka akan stabil bahkan mengalami peningkatan yang signifikan, maka setelah perlakuan ini terlihat bahwa media audio memberikan pengaruh yang signfikan untuk meningkatkan kemampuan hafalan siswa.

\section{Mencari Nilai Mean, Median, Mode, Simpangan Baku, Range, Nilai Maximum dan Minimum}

Berikut gambaran umum tentang mean, median, mode, simpangan baku, range, dan nilai maximum, dari masing-masing variabel dengan menggunakan bantuan program spss for windows yaitu sebagai berikut. 
Tabel. 4.

Statistics

\begin{tabular}{|l|r|r|}
\hline & pretes & Postes \\
\hline Valid & 27 & 27 \\
Missing & 0 & 0 \\
Mean & 66,37 & 63,11 \\
Median & 64,00 & 64,00 \\
Mode & 64,00 & 88,00 \\
Std. Deviation & 11,70 & 22,11 \\
Range & 48 & 72,00 \\
Minimum & 48 & 24,00 \\
Maximum & 96 & 96,00 \\
\hline
\end{tabular}

Sumber: Data Pengolahan SPSS

Adapun pedoman untuk memberikan interpretasi penafsiran sampel mean, median dan modus, peneliti mengutip berdasarkan hasil penelitian Ganjar Prastyo menurut Sugiyono adalah sebagai berikut: ${ }^{16}$

Tabel. 5.

\section{Pedoman Interpretasi Penafsiran}

\begin{tabular}{|c|c|}
\hline Interval Nilai & Interpretasi \\
\hline $0-20$ & Sangat Kurang \\
\hline $21-40$ & Kurang \\
\hline $41-60$ & Cukup Baik \\
\hline $61-80$ & Baik \\
\hline $81-100$ & Sangat Baik \\
\hline
\end{tabular}

a) Analisis deskriptif hasil nilai pretes (X)

Untuk menjawab hasil pretes dapat menggunakan alat ukur sebagai berikut.

1. Mean

Berdasarkan tabel dapat dilihat bahwa nilai rata-rata hitung (mean) menurut persepsi responden adalah sebesar 63,37. Sedangkan skor total yang dihafal adalah diambil dari 20 ayat, maka jumlah tersebut dikalikan dengan skor tertinggi yaitu 4,jadi $20 \times 4=80$. Dengan demikian nilai rata-rata hitung untuk pretes siswa kelas VIII A di Pondok Pesantren An Nawawi Al

${ }^{16}$ Ganjar Prasetyo, Skripsi Pengaruh Kompetensi dan Kepuasan Kerja Terhadap Kinerja Pegawai Kecamatan Ciputat Kota Tangerang Selatan, (Jakarta, Fakultas Ekonomi Universitas Nasional, 2013) hal.92 
Bantani mencapai $(66,37: 80) \times 100 \%=82,96 \%$. Bila ditafsirkan secara kualitas maka termasukdalam interpretasi baik.

2. Median

Berdasarkan tabel dapat dilihat bahwa nilai tengah (median) menurut persepsi responden adalah sebesar 64 atau $(64: 80) \times 100 \%=80 \%$. Dengan demikian nilai tengah untuk pretes santri kelas VIII An- Nawawi Al-Bantani, Bila ditafsirkan secara kualitas maka termasuk dalam interpretasi baik.

3. Modus

Berdasarkan tabel dapat dilihat bahwa nilai yang sering Muncul (mode) Menurut presepsi responden adalah sebesar 64 atau $(64: 80) \times 100 \%=80 \%$. Dengan demikian nilai yang sering muncul untuk pretes siswa kelas VIII A An-nawawi Al-bantani, bila ditafsirkan secara kualitas maka termasuk dalam interpretasi sangat baik.

4. Simpangan Baku

Berdasarkan tabel dapat dilihat bahwa nilai simpangan baku (standard deviation) menurut persepsi responden adalah sebesar 11,70 artinya variabel jawaban tersebut terhadap prestes menghafal siswa kelas VIII An-nawawi Albantani dari nilai yang diberikan kedalam kelompok sebesar 11,70

5. Range

Berdasarkan tabel dapat dilihat bahwa range sebesar 48, artinya jarak antara nilai maximum dan nilai minimum yang dijawab oleh responden terhadap pretes siswa kela VIII An-nawawi Al-bantani sebesar 48.

6. Minimum

Nilai minimum sebesar 48 yang artinya nilai terendah yang dijawab oleh responden untuk pretes adalah sebesar 48 .

7. Maximum

Nilai maximum sebesar 96 yang artinya nilai tertinggi yang dijawab oleh responden untuk pretes adalah sebesar 96.

b) Analisis deskriptif hasil nilai postes $(\mathrm{Y})$

Untuk menjawab hasil postes dapat menggunakan alat ukur sebagai berikut:

1. Mean

Berdasarkan tabel dapat dilihat bahwa nilai rata-rata hitung(mean) berdasarkan hasil tes adalah sebesar 63,11. Sedangkan skor total untuk postes yaitu 96 point yaitu dengan penilaian pada aspek kelancaran = 4 , ketepatan $=4$, kecepatan waktu $=4$, skor tertinggi adalah 96, maka $4 \times 3$ $=12,12$ × $8=96$ point, Dengan demikian nilai rata-rata hitung untuk postes hafalan siswa kelas VIII di SMPIT An Nawawi Al Bantani mencapai $(63,11: 6)$ $x 100 \%=65,73 \%$. Bila ditafsirkan secara kualitas maka termasuk dalam interpretasi baik.

2. Median

Berdasarkan tabel 4.4 dapat dilihat bahwa nilai tengah (median)berdasarkan hasil tes adalah sebesar 64 atau $(64: 96) \times 100 \%=66,66 \%$. 
Dengan demikian nilai tengah untuk postes siswa kelas VIII di Pondok Pesantren An Nawawi Al Bantani, bila ditafsirkan secara kualitas maka termasuk dalam interpretasi baik.

3. Modus

Berdasarkan tabel dapat dilihat bahwa nilai yang sering Muncul (mode) Menurut presepsi responden adalah sebesar 88 atau $(88: 96) \times 100 \%=91,66 \%$. Dengan demikian nilai yang sering muncul untuk postes siswa kelas VIIIA An-nawawi Al-bantani, bila ditafsirkan secara kualitas maka termasuk dalam interpretasi sangat baik.

4. Simpangan Baku

Berdasarkan tabel dapat dilihat bahwa nilai simpangan baku (standard deviation) menurut persepsi responden adalah sebesar 22,11 artinya variabel jawaban tersebut terhadap postes menghafal siswa kelas VIII An-nawawi Albantani dari nilai yang diberikan kedalam kelompok sebesar 22,11.

5. Range

Berdasarkan tabel dapat dilihat bahwa range sebesar 72, artinya jarak antara nilai maximum dan nilai minimum yang dijawab oleh responden terhadap postes siswa kela VIII An-nawawi Al-bantani sebesar 72.

6. Minimum

Nilai minimum sebesar 24 yang artinya nilai terendah yang dijawab oleh responden untuk postes adalah sebesar 24 .

7. Maximum

Nilai maximum sebesar 96 yang artinya nilai tertinggi yang dijawab oleh responden untuk postes adalah sebesar 96.

\section{Penyajian Data Hasil Pretes dan Postes}

a) Penyajian Data Dalam Bentuk Tabel Frekuensi

Tabel.6.

\begin{tabular}{|r|r|r|r|r|}
\hline & & & \multicolumn{2}{|c|}{ Valid } \\
Pretes \\
\hline Valid & Frequency & Percent & Percent & Cumulative Percent \\
& 1 & 3,7 & 3,7 & 3,7 \\
56,00 & 8 & 29,6 & 29,6 & 33,3 \\
64,00 & 9 & 33,3 & 33,3 & 66,7 \\
72,00 & 4 & 14,8 & 14,8 & 81,5 \\
80,00 & 2 & 7,4 & 7,4 & 88,9 \\
88,00 & 2 & 7,4 & 7,4 & 96,3
\end{tabular}




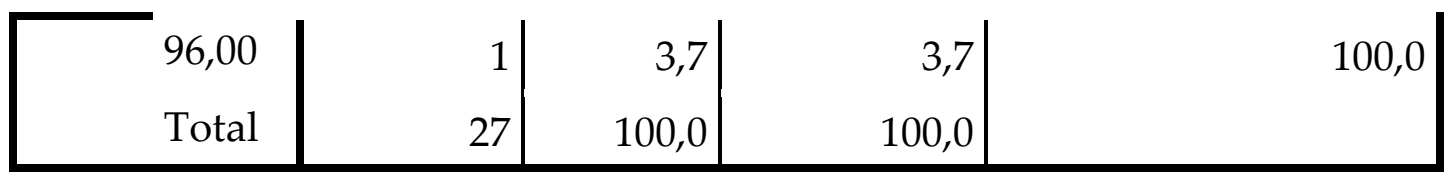

Sumber: Data Pengolahan spss

Dari tabel 4.5 diatas, dipaparkan hasil pengolahan data berdasarkan tes uji lisan, sehingga diperoleh nilai hasil pretes dengan frekuensi masing-masing nilai dengan jumlah responden $(\mathrm{N})=27$.

Tabel. 7.

\begin{tabular}{|r|r|r|r|r|}
\hline & Frequency & Percent & \multicolumn{1}{|c|}{$\begin{array}{c}\text { Valid } \\
\text { Percent }\end{array}$} & Cumulative Percent \\
\hline Valid 24,00 & 2 & 7,4 & 7,4 & 7,4 \\
32,00 & 1 & 3,7 & 3,7 & 11,1 \\
40,00 & 3 & 11,1 & 11,1 & 22,2 \\
48,00 & 3 & 11,1 & 11,1 & 33,3 \\
56,00 & 14,8 & 14,8 & 48,1 \\
64,00 & 3 & 11,1 & 59,3 \\
72,00 & 3 & 11,1 & 3,7 & 63,0 \\
80,00 & 1 & 3,7 & 11,1 & 74,1 \\
88,00 & 3 & 11,1 & 18,5 & 92,6 \\
96,00 & 5 & 18,5 & 7,4 & 100,0 \\
Total & 2 & 7,4 & 100,0 & \\
\hline
\end{tabular}

Sumber: Data Pengolahan SPSS

Dari tabel 4.6 diatas, dipaparkan hasil pengolahan data berdasarkan tes uji lisan, sehingga diperoleh nilai hasil postes dengan frekuensi masing-masing nilai dengan jumlah responden $(\mathrm{N})=27$.

b) Penyajian data dalam bentuk Histogram 


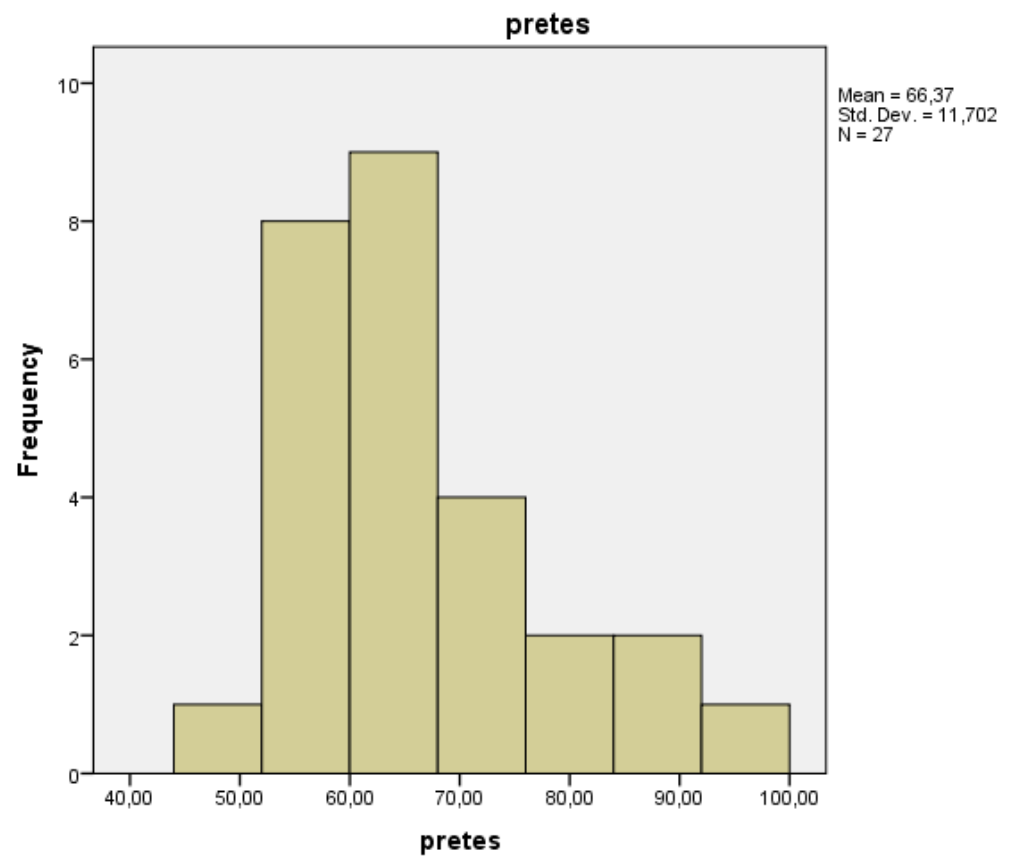

Gambar. 1. Histogram Frekuensi Pretes

Dari gambar diatas, dipaparkan histogram pretes dengan nilai rata-rata $($ Mean $)=66,37$, Standar Deviasi $=11,702$, dan jumlah responden $(N)=27$.

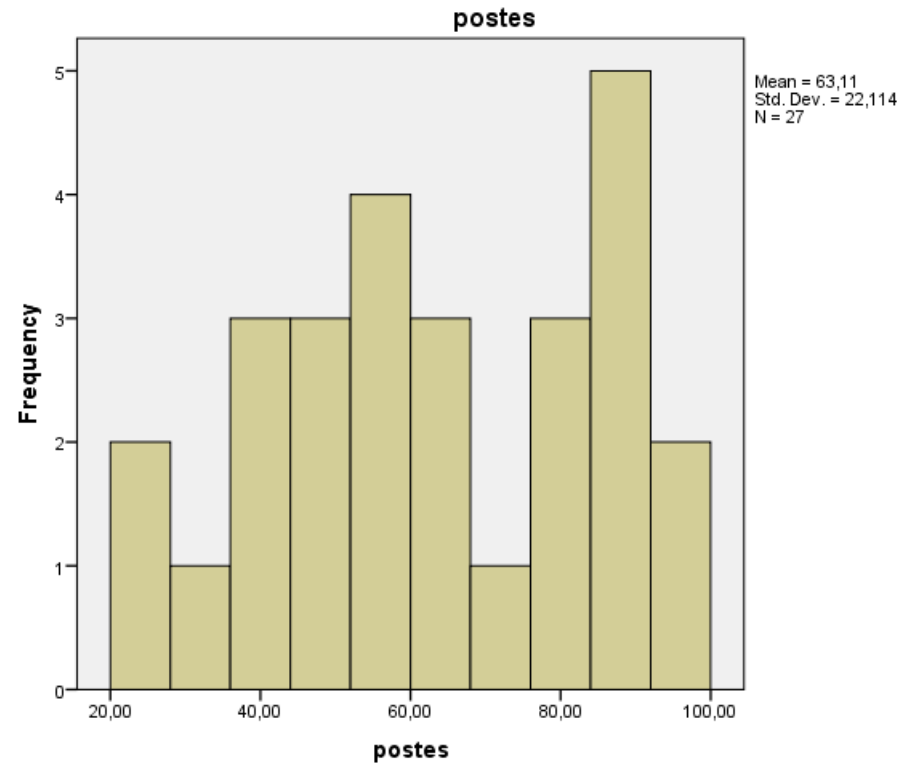

Gambar. 2. Histogram Frekuensi Postes

Dari gambar diatas, dipaparkan histogram uji tes hafalan siswa dengan nilai rata-rata $($ Mean $)=63,11$, Standar Deviasi $=22,114$, dan jumlah responden $=27$.

4) Menentukan Kualifikasi pretes dan postes

a) Menentukan Kualifikasi Pretes Hafalan Dengan Standar Skala 5 


$$
\begin{aligned}
& M+1,5 S D=66,37+1,5(11,70)=83,92 \\
& M+0,5 S D=66,37+0,5(11,70)=72,22 \\
& M-0,5 S D=66,37-0,5(11,70)=60,52 \\
& M-1,5 S D=66,37-1,5(11,70)=48,82
\end{aligned}
$$

Tabel. 8.

Nilai Distribusi Frekuensi Pretes

\begin{tabular}{|c|c|}
\hline Interval & Kategori \\
\hline $81-$ keatas & Istimewa \\
\hline $73-80$ & Baik \\
\hline $65-72$ & Sedang \\
\hline $58-64$ & Kurang \\
\hline $58-$ kebawah & Sangat Kurang \\
\hline
\end{tabular}

Berdasarkan hasil perhitungan mean tersebut, diketahui bahwa mean dari Variabel X (Pretes) adalah 66,37. Hal ini menunjukkan bahwa Pretes menghafal Al-Qur'an siswa kelas VIII Pondok Pesantren An-Nawawi AlBantani termasuk dalam kategori sedang, yaitu pada interval $65-72$.

Tabel. 9.

Hasil Nilai Pretes

\begin{tabular}{|c|c|c|}
\hline Nilai & Frekuesi & Predikat \\
\hline 48 & 1 & Sangat Kurang \\
\hline 56 & 8 & Sangat Kurang \\
\hline 64 & 9 & Kurang \\
\hline 72 & 4 & Sedang \\
\hline 80 & 2 & Baik \\
\hline 88 & 2 & Istimewa \\
\hline 96 & 1 & Istimewa \\
\hline
\end{tabular}

Dari tabel 4.8 tersebut dapat dijelaskan bahwa 11\% responden masuk kategori istimewa, 8\% baik, 15\% sedang, 33\% kurang, dan hanya 33\% yang motivasinya masuk kategori sangat kurang.

b) Menentukan Kualifikasi Postes Hafalan Dengan Standar Skala 5

$\mathrm{M}+1,5 \mathrm{SD}=63,11+1,5(22,11)=96,27$

$\mathrm{M}+0,5 \mathrm{SD}=63,11+0,5(22,11)=74,16$

$\mathrm{M}-0,5 \mathrm{SD}=63,11-0,5(22,11)=52,05$

$\mathrm{M}-1,5 \mathrm{SD}=63,11-1,5(22,11)=29,94$

Tabel 4.9

Nilai Distribusi Frekuensi Postes 


\begin{tabular}{|c|c|}
\hline Interval & Kategori \\
\hline $81-$ keatas & Istimewa \\
\hline $73-80$ & Baik \\
\hline $65-72$ & Sedang \\
\hline $58-64$ & Kurang \\
\hline $58-$ kebawah & Sangat Kurang \\
\hline
\end{tabular}

Berdasarkan hasil perhitungan mean tersebut, diketahui bahwa mean dari Variabel Y (Postes) adalah 63,11. Hal ini menunjukkan bahwa Postes menghafal Al-Qur'an siswa kelas VIII Pondok Pesantren An-Nawawi AlBantani termasuk dalam kategori kurang, yaitu pada interval 58 - 64 .

Tabel 4.10

Hasil Nilai Postes

\begin{tabular}{|c|c|c|}
\hline Nilai & Frekuensi & Kategori \\
\hline 24 & 2 & $\backslash$ Sangat Kurang \\
\hline 32 & 1 & Sangat Kurang \\
\hline 40 & 3 & Sangat Kurang \\
\hline
\end{tabular}

Tabel. 11

Deskripsi Data Statistik Pretes dan

Postes Sttatistic

\begin{tabular}{|c|c|c|}
\hline 48 & 3 & Sangat Kurang \\
\hline 56 & 4 & Sangat Kurang \\
\hline 64 & 3 & Kurang \\
\hline 72 & 1 & Sedang \\
\hline 80 & 3 & Baik \\
\hline 88 & 5 & Istimewa \\
\hline 96 & 2 & Istimewa \\
\hline
\end{tabular}

Dari tabel tersebut dapat dijelaskan bahwa 26\% responden masuk kategori istimewa, 11\% baik, 4\% sedang, 11\% kurang, dan hanya $48 \%$ yang motivasinya masuk kategori sangat kurang.

\section{5) Analisis Hubungan Koefisien Korelasi}

a) Menentukan besar hubungan (korelasi) antara variabel $X$ dan $Y$

Untuk membuktikan kuat lemahnya hubungan dan diterima tidaknya hipotesis yang diajukan dalam penelitian ini, maka peneliti menggunakan analisis statistik yaitu korelasi pearson product moment dengan menggunakan proses SPSS 22, dengan hasil berikut. 


\begin{tabular}{|c|c|c|c|}
\hline & Pretes & postes \\
\hline $\mathrm{N}$ & Valid & 27 & 27 \\
\hline & Missing & 0 & 0 \\
\hline & & 66,3704 & 63,1111 \\
\hline & eviation & 11,70190 & 22,11392 \\
\hline
\end{tabular}

Dari tabel diatas menunjukan jumlah responden $(\mathrm{N})$ sebanyak 27orang, nilai rata-rata pretes menghafal siswa sebesar 66,37, sedangkan nilai ratarata postes menghafal siswa sebesar 63,11. Standar deviasi pretes sebesar 11,70, sedangkan standar deviasi postes sebesar 22,11.

Hubungan antara Pretes $(\mathrm{X})$ dan Postes $(\mathrm{Y})$

Tabel. 12 Correlations

\begin{tabular}{|ll|r|r|}
\hline & & \multicolumn{1}{|c|}{ pretes } & \multicolumn{2}{|c|}{ postes } \\
\hline pretes & Pearson Correlation & 1 &, $893^{* *}$ \\
& Sig. (2-tailed) & &, 000 \\
& $\mathrm{~N}$ & 27 & 27 \\
\hline postes & Pearson Correlation &, $893^{* *}$ & 1 \\
& Sig. (2-tailed) &, 000 & \\
& $\mathrm{~N}$ & 27 & 27 \\
\hline
\end{tabular}

**. Correlation is significant at the 0.01 level (2-tailed).

Sumber: Data Pengolahan SPSS

Dari tabel diatas menunjukan bahwa tingkat hubungan antara pretes dan postes menghafal Al-Qur'an sebesar 0,893, sig sebesar 0,00 dengan jumlah responden $(\mathrm{N}) 27$ orang siswa. Untuk memberikan interpretasi koefisien korelasi dapat menggunakan tabel berikut. ${ }^{17}$

\section{Tingkat Korelasi dan Kekuatan Hubungan}

Tabel. 13

\begin{tabular}{|l|l|l|}
\hline No. & Nilai Korelasi $(r)$ & Tingkat Hubungan \\
\hline
\end{tabular}

${ }^{17}$ Sugiyono, Metode Penelitian Kuantitatif, (Bandung: CV Alfabeta, 2008), 274. 


\begin{tabular}{|c|c|c|}
\hline 1 & $0,00-0,199$ & Sangat Rendah \\
\hline 2 & $0,20-0,399$ & Rendah \\
\hline 3 & $0,40-0,599$ & Sedang \\
\hline 4 & $0,60-0,799$ & Kuat \\
\hline 5 & $0,800-1,000$ & Sangat Kuat \\
\hline
\end{tabular}

Dari tabel menunjukan hubungan antara pretes dan postes sangat kuat (Positif), yaitu 0,893. Arti positif adalah hubungan antara pretes dan postes (variabel X dan Y) searah. Maksud searah disini semakin sering seorang siswa menggunakan media audio dalam metode menghafalnya, maka kemampuan menghafalnya akan semakin baik dan cepat. begitu juga sebaliknya, semakin jarang seorang siswa menggunakan media audio dalam mengafalnya, maka kemampuan menghafalnya akan semakin buruk dan lambat.

b) Koefisien Determinasi

Koefisien determinasi (KD) adalah angka yang menyatakan atau digunakan untuk mengetahui kontribusi atau sumbangan yang diberikan oleh sebuah variabel atau lebih $X$ (bebas) terhadap variabel $Y$ (terikat). Untuk mengetahui besar sumbangan (kontribusi) variabel $X$ terhadap variabel $Y$ digunakan rumus sebagai berikut:

$$
\begin{aligned}
K D & =(r)^{2} \times 100 \% \\
& =(0,893)^{2} \mathrm{X} 100 \% \\
& =79,74 \%
\end{aligned}
$$

Berdasarkan analisis determinasi diperoleh angka sebesar $\quad 79,74 \%$ yang berarti kemampuan hafalan al Qur"an siswa ditentukan oleh penggunaan media audio dalam menghafal, sementara 20,26\% ditentukan oleh faktor lain seperti penggunaan media visual dan tulis. Besarnya persentase hubungan yang diperoleh menunjukkan pentingnya penggunaan media audio dalam upaya meningkatkan kemampuan hafalan al- Quran bagi siswa. Dimana kondisi demikian sekaligus menjelaskan bahwa salah satu upaya meningkatkan hafalan adalah penggunaan media audio.

\section{c) Hipotesis}

Untuk mengetahui ada tidaknya hubungan antara penggunaan media audio dalam meningkatkan kemampuan menghafal Al-Qur'an siswa, maka peneliti menggunakan dua cara yaitu Uji-t dan berdasarkan teknik probabilitas.

\section{Uji-t}

Uji-t merupakan statistik parametrik, untuk mengujinya maka dibutuhkan langkah-langkah sebagai berikut:

f) Membuat hipotesis dalam uraian kalimat 
Ho : Tidak terdapat pengaruh antara penggunaan media audio dengan kemampuan hafalan al Qur'an siswa.

Ha : Terdapat pengaruh antara penggunaan media audio dengan kemampuan hafalan al Qur'an siswa

g) Membuat Hipotesis dalam Bentuk Model Statistik

Ho : $r=0$

Ha $: r \neq 0$

h) Menentukan Kaidah Pengujian

Jika, -ttabel $\leq$ thitung $\leq$ ttabel, maka Ho diterima.

Jika, thitung $>$ ttabel, maka Ho ditolak.

i) Menghitung thitung dan ttabel ${ }^{18}$

$$
\begin{aligned}
\text { thitung } & =\underline{r \sqrt{n-2}} \\
& \sqrt{1-(r)^{2}} \\
= & \frac{0,893 \sqrt{27-2}}{\sqrt{1-(0,893)^{2}}} \\
= & \underline{4,465} \\
& 0,203 \\
= & 21,9
\end{aligned}
$$

j) Menentukan ttabel

Nilai ttabel dapat dicari dengan menggunakan tabel distribusi $t$ dengan cara, taraf signifikan $\alpha=0,05$. Kemudian dicari ttabel pada tabel distribusi student $t$ dengan ketentuan $t(\alpha, \mathrm{n}-2)=t(0,05,27-2)=2,060$.

f) Membandingkan nilai thitung dan ttabel

Tujuan membandingkan ttabel dan thitung adalah untuk mengetahui apakah Ho ditolak atau diterima berdasarkan kaidah pengujian di atas. Ternyata thitung $=21,9>=2,060$, ttabel, maka Ho ditolak.

2. Teknik Probabilitas

a) Membuat hipotesis dalam uraian kalimat

Ho : Tidak terdapat pengaruh antara penggunaan media audio terhadap kemampuan hafalan siswa.

Ha : Terdapat pengaruh antara penggunaan media audio terhadap kemampuan hafalan siswa.

b) Keputusannya

Kriteria keputusan yang diambil berdasarkan nilai probabilitas.

Jika ( $\operatorname{sig})>\alpha$, maka Ho diterima.

Jika (sig) $<\alpha$, maka Ho ditolak.

Dari tabel 4.7 di atas nilai sig sebesar 0,00. 
Pada kasus ini nilai $\alpha=0,05$.

Dari hasil perbandingan antara nilai sig dan $\alpha$, diperoleh:

Sig $=0,00<\alpha=0,05$, sehingga keputusannya Ho ditolak, yaitu ada hubungan antara Penggunaan Media Audio dengan Kemampuan hafalan al Qurean Siswa.

\section{KESIMPULAN}

Berdasarkan data penlitian yang telah diperoleh dapat disimpulkan secara umum, bahwa terdapat pengaruh signifikan dalam penggunaan media audio terhadap kemampuan menghafal ayat al-Qur'an. Hal ini dapat dibuktikan dengan adanya peningkatan kemampuan menghafal ayat al-Qur'an dengan menggunakan media audio yang dikemas dengan cara pengulangan ayat sebagai penguatan pada kemampuan menghafal ayat. Penggunaan media audio berpengaruh untuk meningkatkan kemampuan menghafal ayat al-Qur'an. Media Audio memudahkan proses belajar khususnya dalam menghafal al-Qur'an. Konsep baru yang mengemas media audio dengan cara pengulangan yang akan memudahkan siswa belajar dimana saja dan kapan saja. Sehingga media audio dapat membantu memudahkan proses pembelajaran menjadi lebih menarik. Penggunaan media audio jug mempunyai pengaruh terhadap peningkatan kemampuan ketepatan melafalkan ayat 1-Qur'an, peningkatan terhadap ketepatan melafalkan, kelancaran menghafalkan ayat 1-Qur'an dan peningkatan terhadap kecepatan waktu atau jangka waktu untuk menghafalkan ayat al-Qur'an. Hal tersebut ditunjukan dengan adanya peningkatan dari mulai hasil pretes ke hasil postes. Sehingga dapat ditarik kesimpulan bahwa ada peningkatan kemampuan menghafal ayat al-Qur'an sesudah menggunakan media audio bagi siswa SMPIT An Nawawi Al Bantani.

Hasil Pretes-Postes yang di analisis melalui analisis product moment, maka dapat diambil beberapa kesimpulan yaitu: 1) Berdasarkan hasil data yang diperoleh untuk nilai pretes (sebelum perlakuan)menunjukkan nilai rata-rata pretes menghafal yaitu 66,37\% dengan kualitas baik, nilai median yaitu 64,00\% dengan kualitas baik, nilai mode yaitu 64,00\% dengan kualitas baik,nilai simpangan baku (standard deviation) yaitu 11,70, nilai range yaitu 48,nilai minimum yaitu 48 dan nilai maximum yaitu 96;2) Berdasarkan hasil data yang diperoleh untuk nilai Postes hafalan menunjukkan nilai rata-rata hitung postes hafalan yaitu 63,11\% dengan kualitas baik, nilai median yaitu $64,00 \%$ dengan kualitas baik, nilai mode yaitu 88,00\% dengan kualitas baik, nilai simpangan baku (standard deviation) yaitu 22,11, nilai range yaitu 72, nilai minimum yaitu 48 dan nilai maximum yaitu 96; 3) Dari tingkat kekuatan hubungan antara pretes dan postesmenunjukkan kekuatan pengaruh yang sangat kuat positif sebesar 0,893 .

Hasil dari penelitian yang telah dilaksanakan dapat memberikan manfaat serta gambaran kepada seluruh pihak terkait pengaruh penggunaan media audio untuk meningkatkan kemampuan menghafal ayat Al-Qur'an kelas VII A di SMPIT An-Nawawi Al-Bantani. Keunggulan media audio untuk menghafal Al-Qur'an ini adalah untuk lebih memudahkan siswa dalam menghafal Al-Qur'an kapan saja dan 
dimana saja. Cukup dengan memutarkan MP3 yang lebih praktis sudah di setting dengan pengulangan ayat per ayatnya sehingga menjadi penguat dalam menghafal.

\section{DAFTAR PUSTAKA}

Apandi, Idris, Gerakan Jabar Menghafal, 2015, http://www.kompasiana.com/ idrisapandi /gerakan-jabar-menghafal-al-quran54fd1d81a333113f1d50f85f.

Arifin, Zainal, Penelitian Pendidikan. Bandung: PT.Remaja Rosdakarya, 2011.

Desmita, Psikologi Perkembangan. Bandung: PT Remaja Rosdakarya, 2005.

Fattah, Yahya Abdul, Revolusi Menghafal Al-Qur'an. Surakarta: Insan Kamil, 2010.

Fauzia, Nurul, Pengaruh penggunaan media audio untuk meningkatkan kemampuan menghafal ayat al-quran. Bandung: UPI, 2015.

Gade, Fithriani, "Implementasi Metode Takrar Dalam Pembelajaran MenghafalAlQur'an", Jurnal Didaktika, Vol XIV, No, 2, 2015.

Prasetyo, Ganjar, "Pengaruh Kompetensi dan Kepuasan Kerja Terhadap Kinerja Pegawai Kecamatan Ciputat Kota Tangerang Selatan", Skripsi, Universitas Nasional Fakultas Ekonomi, 2013.

Putra, Rahman Tri, Memori, http://www.memoripedia.byethost7.com/definisi.html 2015.

Sadiman, Arief dkk. ,Media Pendidikan: Pengertian Pengembangan dan Pemanfaatannya, Jakarta: Rajawali Pers, 2010.

Sugiyono, Metode Penelitian Pendidikan. Bandung: CV.Alfabeta, 2008. Metode Penelitian Kuantitatif. Bandung: CV Alfabeta, 2008.

Singarimbun Mari dan Sofian Effendi, Metode Penelitian Survei. Jakarta, LP3ES,1995. 